\title{
Remembering forgotten connections: Klaus Mollenhauer's opening to theorising education differently
}

\author{
Gert Biesta, University of Luxembourg \\ gert.biesta@uni.lu
}

I was recently involved in an exchange on Twitter about the use of notions such as 'subjectivity,' 'subjectification,' and 'subject-ness' in my work (e.g., Biesta, 2010; 2014). ${ }^{1}$ This was in response to a number of tweets in which senders had wondered why we needed such strange and confusing words, and whether what I was trying to say wasn't actually just about 'identity.' Why would there be a need to invent a new word, some senders suggested, if we already have a word that 'says it all'? While I did concede that it was not just a matter of concepts or definition - that concepts in themselves are not really the issue - I did try to say that identity and subject-ness are quite different themes that refer to quite different questions. The question of identity, so I suggested, is the question of who I am, whereas the question of subjectivity is the question of how I am. While both are legitimate questions, they are not only very different questions, but I also suggested that for me the educational interest lies with the second question, not the first one.

This does not mean that education should not be allowed to raise questions about identity at all, but that the ultimate educational interest is with the question of the subject-ness of children and students, that is, with the way in which they can exist as subjects of action and responsibility in and with the world. The fact that I had to make such an effort to show the difference between identity and subjectivity, to argue that there is such a thing as an educational interest, that this has to do with the question of the child's subject-ness, and to make clear that these are actually not new and strange concepts but concepts and ideas that have a respectable pedigree in the history of Continental educational thought (see, for example Gössling 1993), indicated to me that what I see as distinctively educational ways of thinking and speaking cannot be taken for granted - even when one is in conversation with people who care about education (which is how I would characterise those contributing to the Twitter exchange), and even when such a conversation takes place in the Netherlands - a country that, at least for the first sixty or seventy years of the $20^{\text {th }}$ century, has been strongly influenced by continental educational thought but where, in the rush towards international scientific excellence, this connection appears to have been largely forgotten.

The situation is even more difficult in the English-speaking world, where connections with continental and particularly German educational scholarship have been rather sparse, particularly throughout the $20^{\text {th }}$ century when educational scholarship and research established itself in academic circles (Biesta, 2011). In this regard, the developments in the $20^{\text {th }}$ century are quite different from those in the $19^{\text {th }}$ century where, at least when we look at North America, there was a much stronger connection with and influence from continental scholarship - think, for example, of the impact of Froebel and Herbart on North American educational thought and practice in the $19^{\text {th }}$ century, or the wider influence of Hegelianism on educational scholarship, not least through the writings of the pragmatists (Dewey, Mead and James). But as several authors have documented in much detail, over the course of the 
$20^{\text {th }}$ century Dewey eventually 'lost' and Thorndike 'won' (see Lagemann, 2000; Labaree, 2000). Thus, educational research and scholarship in the English-speaking world have increasingly drifted away from more educational modes of thought and action towards views that are either dominated by certain forms of psychology and psychometrics or that stem from sociology and cultural studies.

It is against this background that the release of the English translation of Klaus Mollenhauer's Vergessene Zusammenhänge (Mollenhauer, 2014) is such a significant event, not just because it makes a relatively contemporary German educational text available to an English-speaking audience - which in itself is already a rarity ${ }^{2}$ - but also because this text provides an example of a way of educational thinking and theorizing that is largely absent in and largely alien to main discourses in educational research and practice in the English-speaking world. While the book is, of course, not comprehensive - it does not provide an overview of all that has been said and thought about education in the German-speaking world - it is, in my view, exemplary in its consistent attention to an educational way of looking at education.

I am aware that to talk about educational ways of looking at education may sound rather odd in the English language. ${ }^{3}$ The first response might be something like, "Isn't education our object of study, and isn't it the case that in order to study this 'reality' or this 'phenomenon' we actually need intellectual resources from the 'outside,' such as psychology, history, philosophy, sociology and so on?" One could even draw an analogy and suggest that in order to study banking the last thing we would need is to do it with a 'banking' perspective. Such objections make sense if we approach education just as an object of study that is 'out there' and where research needs to make an effort to understand how it works, what its dynamics are, in order as many would suggest - to generate knowledge to improve what is going on. While this is the predominant way in which the field of educational research and scholarship has developed in the English-speaking world, it's not how this has occurred in the German-speaking context where the idea has been developed that it does make sense to look at education in a particular way - an educational way (or in German: a 'pädagogische' way). This is not so much a distinctive theoretical frame as it is an interested way of engaging with education, that is where the research endeavor shares the interest of education itself, understood as an interest in making the subject-ness of children possible. To think of education as an interested academic discipline does not make it an alien entity within the academic world, as one could argue that disciplines such as medicine and law are also organized around an interest - the promotion of health and the promotion of justice respectively.

All this is important to bear in mind. There is a real risk that reading Mollenhauer's book in English translation makes it look too familiar for those whose main intellectual frame of reference has been formed within English-speaking traditions. Looking at the titles and themes of the chapters, after all, shows quite a lot that looks very familiar - there are questions about 'selecting what to convey,' which is a known issue in the field of curriculum theory; there is reference to 'self activity' and to 'identity,' and, although there are some stranger words such as Bildsamkeit, they appear to be about making children learn, and even a notion like 'upbringing' although perhaps not the most common word in the context of school education, does make some initial sense. While all these concepts are helpful in drawing the reader into the book, there is a risk that, because of this, the book could remain a little too familiar. This is partly an issue of translation - and translation, as the translator of the book notes, remains in a sense an impossible task, not least a translation between two quite different paradigms of educational scholarship. But it is also an issue of reading, 
and what I am trying to hint at is the importance of trying to read this book in an unfamiliar way, as a book that precisely engages with questions that, at first sight, may be outside of the realm of what 'makes sense.'

From this angle I do think that the very brief "author's note" on page xii of the translation provides a helpful 'key' for such a way of reading. It is where Mollenhauer refers to a quote from Herwig Blankertz as a 'good motto' for the book. In German, the quote is as follows: "Das Ganze der Pädagogik, die Erziehung, enthält einen szientistisch nicht einholbaren Sinn." In English, this is translated as: "The whole of education, of upbringing, has a meaning that cannot be subsumed to science and scholarship." The translation already poses some problems as 'Pädagogik' is probably more accurately translated as 'the theory and the practice of education' - whether it is theory or practice is always slightly ambivalent in German. What is interesting is that Blankertz specifies this by using the word 'Erziehung,' not the word 'Bildung,' which means that he is not referring to general processes of formation or enculturation, but to deliberative activities on the side of educators to bring children to a form of maturity. How this maturity is understood - for example in terms of rationality or in terms of ethical maturity - is a matter of further discussion. But what is more important here is the choice of the word 'szientistisch' which comes very close to what the word 'science' means in the English language, namely the domain of the natural sciences as distinguished from the domain of the humanities. That is why I would not translate this with 'science and scholarship' but only with 'science' - also because Blankertz is not using the German word that would have covered both, namely 'Wissenschaft.' And then Mollenhauer is saying that what he is trying to do in the book is to refer to and engage with aspects of the 'reality' of education that cannot be 'captured' by science.

Yet the point Mollenhauer is making here 'via' Blankertz is not only, I think, the question what kind of knowledge is able to capture the meaning of education, but he hints at the fact that the 'dynamics' of education partly take place outside of the realm of what can be known. There are, to put it differently, aspects of the 'meaning' of education about which there is nothing to know. ${ }^{4}$ What might this be about? Let me briefly highlight one line of thought in the book that, in my view, exemplifies this - a line that precisely has to do with the question of subjectivity or, with a slightly more precise word: subject-ness, that is, the being-subject of an individual human being. Mollenhauer raises the point in chapter 4 on Bildsamkeit - which we might translate, in this case, as the child's ability to form itself or, in the language Mollenhauer uses here, the child's ability to learn and, more importantly, their willingness to learn. Mollenhauer explores this against the background of his earlier discussion about the way in which the school curriculum has emerged as a representation of life 'itself' and the question of how children might become motivated to engage with such an artificial 'construction.' From a psychological angle this 'problem' is presented as the problem of motivation, which then raises all kinds of technical and technological questions about the ways we might increase the (intrinsic or extrinsic) motivation of children. Thinking of the problem in this way makes it precisely into something about which science has a lot to say; for example, by trying to measure levels of motivation and by trying to devise effective interventions to increase motivation.

But this is precisely the approach Mollenhauer rejects - and in chapter 4 he does so by, on the one hand, trying to hint at the impossible to 'pin down' the subjectness of the child and, on the other hand, to argue that the educational formation of the child's subject-ness is not to be understood as a kind of cultivation - where children are seen "as if they were material to be changed and formed" (Mollenhauer 2014, 
p.65). Through a number of stories and examples Mollenhauer rather tries to show that the child's 'Bildsamkeit' - the ability and willingness to learn - and hence the child's subject-ness, the child's appearance as a subject of learning, emerges as a result of a confrontation with what the child is not. This confrontation manifests itself not only in the form of expectations about what the child might be or become, but also as the projection of a possible future that is articulated in such expectations. From this, Mollenhauer concludes that it is the "challenge posed by the projection of that which I could be that creates an impulse for Bildung and is the precondition for Bildsamkeit to become reality" (ibid., p.75). Hence Bildsamkeit "is not like a plant that blossoms spontaneously in a warm climate, but is instead a disposition that is articulated by the child when he or she is engaged with another's expectations" (ibid., p.74).

One could say, therefore, that what Mollenhauer is trying to show is that education works with fictions - that its dynamics precisely have to do with bringing something in that is obviously not there and, more strongly, that it is not there is some kind of potentiality that just would need to be cultivated. The expectation that at the same time shows a possible way of being for the child is precisely the very thing that is not already 'inside' the child, but comes from the outside: "in a dialogical relationship, in a kind of mutual interchange or call and response" (ibid., p.65). Later on in the book, in his discussion on identity, Mollenhauer indeed states explicitly that identity only exists as a fiction "which, like all fictions, cannot be pinned down empirically or objectively, but that is essential for the process of Bildung" (pp.117118).

This is, of course, just one element of the many intriguing ideas and insights that Mollenhauer presents in Forgotten Connections. Yet my reason for highlighting it is to provide an entry point for a significantly different form and tradition of educational scholarship. This is a form of educational scholarship that precisely does not seeks to generate psychological or sociological or, more generally, scientific knowledge about how education works on the assumption that when we know more about the child, about its development, about its social position, and about all the variables that influence these processes, we can improve the 'quality' of education until we reach some state of perfection. It rather reveals the fundamental importance of a not-knowing, of working with fictions so we might say, in the educational ambition to call the child's subject-ness into being.

\section{Endnotes}

i. The exchange took place in September 2014 and was conducted in Dutch. For some traces see www.twitter.com/gbiesta

ii. To my knowledge Wolfgang Brezinka is one of the very other $20^{\text {th }}$ century educational scholars from Germany whose work has been translated into English - perhaps, but this is just a hypothesis, because his outlook is strongly framed by Popper's critical rationalism and therefore more easily recognizable in the English-speaking world.

iii. In Biesta (2011) I recount the story of the feedback I once received from a reviewer from the English-speaking world on a paper in which I suggested the need for asking educational questions about education. The reviewer wrote that "to suggest that one can ask educational questions about education is as non-sensical as suggesting that one can ask coockery questions about cooking." This paper might also be helpful for readers who are interested in 
38 Biesta

the very different history of educational thought and scholarship in the English-speaking world and the German-speaking world.

i. This also shows, in an interesting way, a fundamental problem with the idea of evidence-based education; a notion that did not yet exist in that way at the time when Mollenhauer wrote his book.

\section{References}

Biesta, G.J.J. (2010). Good education in an age of measurement: Ethics, politics, democracy. Boulder, CO: Paradigm Publishers.

Biesta, G.J.J. (2011). Disciplines and theory in the academic study of education: A Comparative Analysis of the Anglo-American and Continental Construction of the Field. Pedagogy, Culture and Society 19(2), 175-192.

Biesta, G.J.J. (2014). The beautiful risk of education. Boulder, CO: Paradigm Publishers.

Gössling, H.J. (1993). Subjektwerden: Historisch-systematische Studien zu einer pädagogischen Paradoxie. Weinheim: Deutscher Studien Verlag.

Labaree, D.F. (2000). How Dewey lost: The victory of David Snedden and social efficiency in the reform of American education. In D. Troehler, T. Schlag \& F. Osterwalder (Eds), Pragmatism and modernities (pp. 163-188). Rotterdam: Sense Publishers.

Lagemann, E. (2000). An elusive science: The troubling history of educational research. Chicago: University of Chicago Press.

Mollenhauer, K. (2014). Forgotten connections. On culture and upbringing. London/New York: Routledge. 